\title{
The Role of School and Family in Developing Childrens' Literary Creativity
}

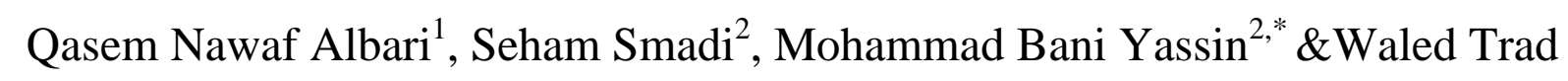

\author{
ALShammari $^{3}$ \\ ${ }^{1}$ Department of Curricula and Instruction, AL - AalBeit University, Jordan \\ ${ }^{2}$ Department of Basic Sciences, Ajloun University College, AL- Balqa ' Applied University, \\ Jordan \\ ${ }^{3}$ Ministry of Education, Saudi Arabia \\ *Corresponding author: Department of Basic Sciences, Ajloun University College, AL- \\ Balqa ' Applied University, Jordan. E-mail: mfozy2@gmail.com
}

Received: May 1, 2013

doi:10.5296/ije.v5i3.3620
Accepted: June 20, 2013 Published: August 20, 2013

URL: http://dx.doi.org/10.5296/ije.v5i3.3620

\begin{abstract}
The study aimed at investigating the role of school and family in developing the literary creativity for children by investigating the concept of creativity, the factors of developing it in childhood, its basic elements and it also aimed to identify creative thinking motivations , characteristics of creative individuals, factors of creativity development in childhood stage and the environmental barriers facing creativity . The study also focused on identifying the proposed activities for the development of literary creativity in writing short story. The researchers used the descriptive method. The findings showed that developing creativity for children is the responsibility of school and family. In addition, the school should be a creative ideal example for the children by offering creative activities to develop the children's', creative tendencies, in addition to the necessity for cooperation between the school and family to make creativity. In light of the above mentioned findings, the researchers recommended a number of relevant recommendations.
\end{abstract}

Keywords: role of school; family; developing children’s; creativity 


\section{Introduction}

Each person has different activities and talents but the ways in which those activities and talents are displayed are different. (creativity is the only thing an individual can do effectively to establish his / her own presence. The modern world is concerned with the creators in order to give solutions for the human problems, such as the alternative energy ,fighting, current diseases and war and peace. The elements of creative schools are represented by the creative teacher, students and administration .The creative teacher and administration are the ones who could light up the creative energy of the students and reveal the individual differences for them (ALKanani ,2011). The classroom should be attractive and sunny not as wood store (Abdel Majeed, 2005).Childhood has become the main concern for parents, educators and thinkers because of its importance as the basic stage in building up the human being. So, each life experience that is offered for children contributes in preparing them in the best way (Abu Alnaser, 2003). In fact, the family plays a big role in developing the children's abilities in dealing with problems in creativity. Those children are born with the seed of creativity and the family works on caring such creativity or vanishing it (Abdel AL, 2005). Islamic education has given a high rank for childhood as being the most influential on the future of individuals and groups. The parents should be highly aware of their responsibility in raising their children correctly mentally, psychologically, socially and in having faith, as well. In addition, having consideration for the external influences on the children (Abdallah, 2001). Developing the children's creativity is possible because each child has a heaven creativity ability that could be enhanced and refined by the way of bringing up (Oweis, 2003), Al Zahrani(2003:337) pointed out that" the ability of creativity is not exclusive for the elite, but it is available for all individuals and parents could affect their children positively". Abu Alnaser (2003) assured that it is necessary to encourage the creativity in childhood rather than in the late stages. Therefore, developing creativity could be achieved through practice (AL Kanani, 2005). Creativity is delivered naturally among people because all of them have creativity in different degrees (Kropli, 2006:19).In spite of having many studies about creativity, there are still some areas that have not been studied. This study attempts to get through such areas.

\section{Problem of the Study}

Developing creativity has a great role in the progress of nations. In Arab World, we are still depending on the creative thought that is exported from the west whether in science, literature or in art. This means that we are still consumers rather than creators because no good caring is available for the creative minds. The family faces a real challenge in raising the creative child and in dealing with the gifted one by feeding his continuous desire for knowledge and exploring the unknown. Because of the great necessity for creativity at this time, it is compulsory for school and family to contribute in developing creativity for children. Therefore, this study is to offer awareness for teachers about the importance of creativity and how to contribute in developing their students' creativity to produce new and fruitful thoughts. Abu Reziq's study (2002) recommended conducting more studies that propose new programs 
for developing the creative written composition for the students. Specifically, the study attempted to answer the following questions:

1. What is the role of school in developing the children's creativity?

2. What is the role of family in developing the children's creativity?

3. What are the school's and family's proposed activities for developing the creative children's literary abilities?

\section{Significance of the Study}

This study is significant because it assures the development of creativity for children as it attracts the attention of the educationalists and practitioners about creativity development. The school contribute in developing creativity for the students simplifies those educationalists, mission by offering creative children. Thus, those educationalists could finish up the role of school in the schooling advanced stages in caring about those creative abilities of the students. Therefore, the school contributes in having a cooperative atmosphere between teachers and parents in establishing a creative generation.

\section{Methodology of the Study}

The researchers used the descriptive method that includes description, interpretation and analysis in human sciences: religious, social and cultural (AL Assaf, 2000:189). The use of this method shows up the educational role of the teachers and the ways they offer for developing the students' creativity, in addition to other roles the teachers have in developing their students' creativity. The descriptive method used in this study does not aim at describing the phenomena or reality but reaching two conclusions contributing in understanding the reality and improving it (Obeidat, 2001:192).

\section{Limitations of the Study}

The study is limited to:

1. The basic stage of primary learning in Jordan from (1- 6) stage.

2. The creative literary development for the students in one domain of literary domains which is the story writing creativity.

\section{Definition of Terms}

Creativity in language: It is derived from the word create which means establish or start. The creator is the establisher not as others in his deeds. God says: "original or of the heavens and the earth" (surah (117): al- Baqarah). This means that God creates them with no example 
like him or his work, finding them from nothing (I bin Manzour: 1997).

Creativity as an idiom: It is a mental activity or a process that offers a serious, original and valuable product for the community including good solutions for the thoughts, problems and curricula (AL AShmawi, 2009). The researchers defined the creativity as teaching the students how to think in new, unfamiliar and useful ways.

Children: Those in the basic stage from grade one to grade six and (6 -12) years.

\section{Related Studies}

The researchers dealt with six studies which are arranged chronologically. Al Shaniqeti(2005) conducted a study aimed at investigating a proposed perception about developing creative thinking for the secondary stage students from the perspective of Islamic education. The researcher used the deductive and inductive methods. The findings showed the necessity of creative thinking and its development. Its importance and its clear effect in the progress and flourishing of nations, in addition to its role in solving the different problems the human beings face. The findings also indicated that the Islamic education considered the mind and the different kinds and aspects of thinking including the creative thinking by using many ways. The most prominent one is that the mind is the greatest bless God donates to people. In addition, a call for reading the verses of Holy Quran thoroughly and considering the world examples of God creation. Moreover, to attract the distinguished ones and to show up the extra mental creative ability persons to guide them to the right solution.

Mohammad and Abdel Majeed (2005) conducted a study aimed at investigating the effectiveness of a proposed program by using brainstorming in developing writing stories. In addition, to find out the effect of this program in developing what is after reading comprehension for the participants, and the relation between the cognitive achievement in story domain and writing a story, in addition to the relation between writing stories and the skill of after reading comprehension. The sample consisted of (15) gifted students from the faculty of education (9) males and (6) females. To achieve the objective of the study, a story element program was developed by using the brainstorming way, achievement test for story elements, writing story test and measuring what is after reading comprehension. The researcher applied pre-test and post-test on the participants. The findings showed differences in story writing test in favor of the post-test. In addition, the findings indicated statistically significant differences between the students' degrees in writing a story and their degrees in the measurement of what is after reading comprehension. Al Nakhali (2004) conducted a study aimed at developing in the abilities of creativity for a group of elementary stage students by sharing in a training program for developing the abilities of creativity. The sample consisted of a group of the fifth grade students in Al Ta'ef governorate. The findings indicated statistically significant differences between the means of the degrees of the experimental group and the controlled one the abilities of creativity (flexibility, eloquence, originality, giving details) in thinking in the post-test in favor of the experimental group. Al Ghamedi's study (2001) aimed to identify the creative thinking abilities for the middle stage 
student in the public schools and the middle stage for reciting and keeping Holy Quran by heart in Jezan area and the difference between them in creative thinking abilities. The findings showed statistically significant differences in the creative thinking between the middle stage students in public schools and the Holy Quran keeping by heart students. In addition, the findings indicated statistically significant differences in the creative thinking between the first and second grades in the middle stage in favor of the first grade. Mosa's study (2002) aimed at identifying the suitable writing story skills for the basic fifth grade and the levels of the students, in addition to clarifying the effect of the proposed program in teaching the story for developing the story skills for the participants and its effect in developing the story awareness for them. The sample consisted of two groups, experimental and control from the fifth grade who were chosen randomly. The findings indicated an effect of the program in developing the story skills and the story awareness in favor of the experimental group. Cormack's study (2004) aimed at identifying the effect of creative drama as a previous strategy for writing process in the writing content and writing a story. The sample consisted of the sixth and seventh grade students: one class has been taught drama lessons and the other was taught the pre-writing processes only. The limitations of the study were nine categories to be measured (thoughts and characters, dialogue style). The findings showed a positive effect for the use of creative drama as a pre-writing activity. In addition, the findings showed that the students who watch drama stories for a long time have used the dialogue in a better way and wrote narratively, in addition to improving their writing style especially the plot, characters and the background description. The findings also indicated that those who studied drama were more positive in pre-writing activities.

\subsection{Commenting on the Previous Studies}

Most studies assured the importance of the creative thinking, the abilities of creativity and developing creativity for the students, such as Al Ghamedi's study (2001), Al Nakhali's study (2004) and Al Shanqeti's study (2005). Some studies assured the importance of Holy Quran keeping by heart in developing the creativity like the study of Al Ghamedi (2001). Some studies also focused on developing creativity for the basic stage as Al Nakhali's study (2004), Al Ghamedi's (2001) and Mosa's (2002). Some studies were different in the method, for example Al Ghamedi (2001) used the comparative descriptive method, Al Shanqeti (2005) used the deductive inductive method, whereas Al Nakhali (2004), Mohammad and Abdel Majeed (2005), Mosa (2002) and Cormack (2004) used the semi- experimental method. Some of those studies have assured the effectiveness of teaching by applying different teaching methods for increasing the students', achievements, problem- solving, cooperative learning and brainstorming as Mohammad's and Abdel Majeed's Studies (2005).

\subsection{What makes this Study Significant}

1. Considering the problem of the study by developing the creativity for the basic stage students.

2. Focusing on one kind of the abilities of creativity which is the story; whereas most studies developed their programs to suit two kinds of abilities of creativity, such as article and dialogue. 
3. Focusing on the role of the teachers in developing creativity as being the second backup after the family.

The researchers benefited from the used methods, the statistical procedures, data analysis and some of the recommendations from the previous studies.

\section{Definition of Creativity}

Creativity is a mental, cognitive process including flexibility, originality and giving details. It is considered an advanced mental phenomenon in which the individual deals with situations, experiences and problems in a creative way or by putting forward a collection of solutions to get one good solution (Al Ashmawi, 2009). Gilford's definition of creativity that is mentioned in Obeid's (2000) is "the readiness characteristics that include the freedom and flexibility of thinking, originality and sensitivity to problems, redefining the problem and clarifying it by details", Abu Jadu (2004) considered creativity as a form of leadership in which the creator practices a personal clear influence on others. The creative environment is the atmosphere that includes the situations and condition, that simplify the creativity (Hijazi, 2006). The researchers point out that creativity is a compound mental purposeful activity guiding a strong desire in searching for solutions or reaching original results that haven't been known before. There is a difference between creativity and intelligence: intelligence tests measure the ability to find a correct answer for each question, whereas the creativity is the ability to find new and abnormal answers for different problems (Qatami, 2005). Creativity is different from a gift (talent); the talent in painting for example, is the technical ability to paint a beautiful portrait but this doesn't give the possibility to make this portrait unique with all what it holds of sensation as being seen by anyone (Abu Al Naser, 2003).

\subsection{Thinking and Thinking Skills}

Thinking is mental processes taking place in the mind, the brain does it whenever being exposed to any impressive situation received by the senses. It is a mental activity seeking a solution for any situation. It could be identified by its outcomes. As for thinking skills, they are limited mental processes being done and used purposefully to treat the stimulus, such as identifying the problem, comparison, classification, prediction and remarks (AlTeti, 2001). There is a difference between thinking and thinking skills. Thinking is a total process treats sensitive mental incomes and the translated information to form the thoughts or judge it. It is a misunderstandable process including perception, previous experiences, aware treatment and intuition. As for thinking skills, they are specific processes being practiced and used purposefully in dealing with information like the skills of identifying a problem, finding unmentioned hypothesis in the text or assessing the evidence (AL Kanani, 2011). Creative thinking is a compound purposeful mental activity guided by a strong desire in finding solutions. It is comprehensive and at the highest level of complicated thinking because of including interrelated components of cognition, emotion and morals that form a unique mental status (Jarwan, 1999). Habash (2002) also defined creative thinking as away used by the individuals to have the maximum amount of thoughts about their problems (freedom of 
thinking). Such thoughts are variables (flexible) and not repeated or common (originality). Thinking in general is a mental activity different from sensation and perception which is abstract. Specifically, it is the sequencing of thoughts provoked by a problem or an issue that demands solutions. It leads to checking up the data and finding out the rules and mechanism that is used to work out with (Hussein, 2007).

\subsection{Types of Thinking}

Thinking has different related types are not completely different from each other (ALTeiti, 2001):

1. Creative thinking: It is the mental activity and the ability of perception for the invisible ties among things, events and phenomena. Educationally, creative thinking is the student's ability to offer new solutions for the problems or the situations s/he faces whether its components are available in the classroom or known for the teachers but unknown to the student.

2. Basic thinking: It is the uncomplicated mental activity demanding a practice for the skills of basic thinking (remembering, understanding, application).

3. Multi -thinking: It is the mental activity in which the individual could produce a number of solution by checking the problem from different angles.

4. Lateral thinking: It is the mental activity searching for solutions, ways and suggestions before decision making. The best way to urge the student to think in such way is the dialogue, imagining, picturizing, redescribing and thinking of the issue from different angles.

5. Vertical (concentrating) thinking: It is mental activity leads the individual directly to the solution. It is similar to logic and scientific thinking by focusing on introductions, findings and the real events and not focusing on the side branches. It is one way thinking.

6. Scientific thinking: It is the mental activity that takes place according to organized steps leading to uncovering the scientific rules (laws) by depending on observation, measurement and experimenting.

7. Logic thinking: It is the mental activity based on true results or hypothesized by logic measurement or by forming results based on true introductions.

8. Critical thinking: It is the mental activity demanding the use of higher cognitive levels in Bloom classification(analysis, structuring, assessment).

\subsection{Creativity and Invention}

Creativity is different from invention where the second has higher level. The human being could achieve creativity while being proceeded by others or being equal with them, whereas when reaching or achieving something no one else has done before, it is invention(Jarwan, 2002). Al Sairafi (2006) differentiated between creativity and invention by considering the 
second as the materialist part related to execution and it is a part of creativity because there is no invention without creativity. Many researchers mentioned synonymous terms for creativity as invention means creativity, such as discovery, originality and inspiration (AL Maitah, 2007). All children have the readiness for invention and by training and practice those invention become true. The skill of creativity demands practice to grow up and without practice even the ability for writing, painting, and singing might be lost (ALkanani, 2011).

\subsection{Basic Components for Creativity}

1. Originality which is being distinguished in unique thinking, and the ability to go for the unfamiliar of thoughts. It is also the seriousness and being the one in generating originality which is the most important component for creativity and new thoughts which is the line for judging the level of creativity by producing what is unfamiliar. Al Sairafi (2006) stated that originality is the individual's ability to produce the maximum amount of indirect responses and uncommon and unaccepted thoughts.

2. Eloquence which is the ability to produce many verbal and performant thoughts for a problem of free and open end or the ability to generate a number of alternatives, synonyms, thoughts, problems or usages when responding to a specific stimuli quickly and easily caring of quality rather than quantity. By being eloquent, an individual could produce the maximum amount of thoughts and suggestions at certain period of time (Oweis, 2003). Mind is eloquent in pushing up new thoughts (ALkhalil, 2005). Eloquence includes multi thoughts that could be recalled or the quickness in which the usages, synonyms and the benefits of specific things could be recalled, in addition to the flood of thoughts and the easiness in generating it (Qatami, 2005). Eloquence could be summarized in the following kinds:

- Word eloquence which is the quickness of the individual's thoughts in giving words in a good context.

- Semantic eloquence which is producing the maximum number of words having the same meaning.

- $\quad$ Thought eloquence which is recalling a big number of thoughts in specific period of time.

- Shape eloquence which is introducing some additions to specific shapes for having real paintings and drawing many different shapes (ALkanani, 2011).

- Expression eloquence which is the ability to express thoughts and the easiness of structuring it in words or pictures to have related thoughts expressing a specific topic (ALAzah, 2002).

- Motion eloquence which is the ability to give the maximum number of suitable motion responses in a suitable period of time (ALMa'itah, 2007).

3. Flexibility which is the changing of mental status for the individual or the ability to generate different and unexpected thoughts and to gauge the thinking track with the 
changing of the stimuli or the individual's ability to change or to adapt when it is necessary. The focus is on the quality in creativity and so the creative individual's thoughts are variant(Tafesh, 2004). Flexibility has two aspects:

- Spontaneous flexibility which is giving multi different thoughts related to a specific situation. In this kind, the individual could produce suitable responses for a problem or a stimulus situation (ALkhalailah, 1997).

- Adaptive flexibility which is having a solution for a problem or a situation in light of the feeding back of that situation. Al Sairafi (2006) stated that "adaptive flexibility is the ability of the individual in modifying his/her behavior to solve a problem or to face any situation". It is the ability to move from one behavior into another until having problem solving.

4. Sensitivity to problems which is the individual's ability to find out the problems in things, habits or systems and to discover the weak points is the awareness of having problems or needs or the weak components of the environment or the situation (Oweis, 2003).The creative person realizes things unnoticed by others because of having high sensation towards the problems. Individuals are different in the degree of their sensitivity towards problems as the one's sensation is varied towards each problem by finding put solutions for problems and learning out other problems without solutions.

5. Expanding details which is the ability to add new variant details for an idea or for solving a problem enhancement or execution. Creative children have tendency towards more irrelevant details to their stories or drawings (Oweis, 2003).

6. Assessment ability which is any creative action that includes assessment. The ability for assessment is a suitable creative ability to know the points of weakness and strength and the originality in the creative outcome (AL Sairafi, 2006).

\subsection{What are the Characteristics of the Creative Individual?}

The creative person is renewal and bold in overcoming the expected limitations in thinking without being stopped by wrong probabilities. This individual is distinguished having distinguished work, in addition to having special qualities that help in enhancing his/her production and let him/her feel happy and be a problem solving person.

The creative persons having the following characteristics:

1. Mental qualities that include the ability of noticing the details in parallel with the ability of having multi angles for perceiving one thing, in addition to the unfamiliar vision for the familiar things with high concentration for long independency in thinking. Having also a special philosophy for things while being slow in analyzing the information and quick in restructuring it to find out the solution. The creative individual is always questioning and tends to deal with variant complicated stuff while being highly capable of summing up the opinions and following up the observations in a very strong memory (AL Sweidan and AL Adluni, 2009). 
2. Psychological qualities as being optimistic and enthusiastic and having a vision of new chances for enhancing everything. All that based on high self_confidence, strong will, and being initiative in carrying out the personal projects while depending on internal sensation and feeling towards things and events. Those are easily adapted with variations because of their tendency to venturing, experimenting, exploring and travelling. They are highly responsible and patient in spite of failure situation or being opposed by others (Fred, 209).

\subsection{Motivations for Creative Thinking}

There are different motivations pushing forward the creative thinking. These are:

1. Self - spiritual motives which are related to the person him/herself and the desire for serving the community as a motive encouraging the individual to gain the satisfaction of God and to serve his/ her country relating that to the values and principles ( morals) $\mathrm{s}$ /he gained, in addition to the spiritual estimation and self-esteem. Each person needs to be distinguished to get much more appreciation(Bakaar, 2001).

2. Environmental motives which are related to the demand of creativity in the community (art, scientific, vocational creativity or others). The world is continuously and rapidly changeable which urges searching for solutions to cope with the changing and to contribute in flourishing the communities. The organizations seek for increasing its competitive ability through creating new applicable thoughts to achieve universal reputation to perceed others in a specific purchase or service. This kind of competition takes them to creativity and creative thinking that could help in being distinguished even for a specific period of time not necessarily short (Fared, 2009).

3. Materialistic motives. It is the materialistic outcomes an individual could earn for his/her creative work, such as money, promotion or compliments and fame. Prophet Mohammad(PUH)described the believers those who like collecting money from good ways and spending it in good ways, too (Haj Ali Beik, 2009).

4. Factors related to creative work which is the great desire for finding out a creative idea. This wild desire converted to brain to be treated in order to connect things together and take what is good (AL Sweidan and AL Odwan, 2009).

\subsection{Motivations for Creativity}

Creativity has motivations and factors provoking and guiding it towards achievement. Those are:

a. Environmental factors like the freedom of thought, the availability of time, the use of brainstorming and methods of work and studies that lead to inference not to dictating, in addition to having a good atmosphere for accepting the new opinions, protecting the creators communicating with higher authorities, such as the family, administration, the government and encouraging the individuals of creativity. It is necessary to publicize a general philosophy that encourages creative thinking and being initiative without having fear of failure or punishment, in addition to having the suitable 
authority and putting aside money as rewards for the creators (Fareed, 2009).

b. Self - psychological factors, such as loyalty, good reputation, honesty, in addition to heavy burden, mind pressure, team work, scientific methodology in thinking, rich background and imagination and clarity of objectives. "Each one has the ambition and the desire to be distinguished and finding a continous objective is away to express the ambition and the level of personal commitment (Tawfeeq, 2005).

c. Practical factors as writing down the quick thoughts, positive thinking, optimism, slowing down and concentration, (AL Sweidan and AL Adluni, 2009).

\subsection{Why is Creativity a Life Necessity?}

Generally speaking, thinking is the use of human mind where the individual looks thoroughly at everything around to understand and interpret, even the animal could understand. In this respect, Humway stated that thinking takes place in the creature's experience whether it is human or animal whenever facing or identifying a problem and attempting to solve it(Bakaar, 2005).Exploring the highest laws that rule the universe by the brain is called by the scientists the global rules that are comprehensive for all creatures and everything in this life is ruled by such laws. The complicated modern communities nowadays and its instability is due to the technological variations which are accompanied by social expectation. Traditions have become not convenient for facing the new inventions and also the basic knowledge hasn't been restricted by reading and writing (AL Khaleeli, 2005).

\subsection{Islam and Creativity}

Creativity is one of God's names for creating everything on earth (IbinManzour, 1997). Freedom of creativity in Islam is disciplined. The creative Muslim is connected with the instructions of Holy Quran to be committed to achieve honesty in every done work. Creativity is an internal mental need for human kind which should be verified to accomplish the wanted objectives for the good of the community. Therefore, creativity is a mental need for human being exactly as physical and psychological needs, such as comprehension, cognition and developing the creative abilities (AL ALBani, 1986). Creativity meets important individuals need, such as independency, curiosity and exploring and experimenting scientifically (Abdel ALl, 2005). Creative education is considered the way for information age and the way of getting rid of cultural retardations learning is Holy Quran and keeping it by heart which is an important element in developing the children's creativity and refining their small creations and increasing their skills and abilities. The best example for creative Muslim children who were brought up according to learning Holy Quran, reciting and keeping by heart, as well Ibinkhaldun, IbinRushd, Ibinseena and others( AL- Huwaidi, 2004).

\subsection{The Factors that Develop or Block the Children's Creativity}

Creativity could be noticed very early through the children's expressions, their games and then through their different activities inside and outside the school. The growth and development of such abilities extend from late childhood up to the beginning of adolescence. Those abilities might slow down in the adolescence stage or continue steadily (Oweis, 2003). 
Increasing or decreasing the creativity abilities is due to the adolescent him/herself in facing the practical life, concerning with school achievement, imitating adult's behaviors and abandoning the activities of creativity that add noting in acquiring the available social rank. There are different factors slowing dowing the creativity ability in different age stage until the end of adolescence stage. These are:

- From (5-6) years, the child is ready to join the school and s/he is demanded to be obedient and good- mannered. If the way of treating him/her is was very strict and oppressed it will take away and choke the creativity.

- From (7-10) years the need for joining a special group is shown up and this demands a specific position for the child among the group. This demands from the individual kind of obedience to the group rules to be accepted. Being stuck to the activities and rules of the group decreases the creativity abilities.

- From (13-15) is the beginning of adolescence stage which is accompanied with social pressure related to the relation between boys and girls and what should and shouldn't be done, in addition to the obedience of the group rules which all block the creativity abilities which make this stage more complicated and challenged for the individual.

- From (17-19) the individual begins choosing a profession and if the regulations of such profession are strict, the creativity abilities could be totally choked (Oweis, 2003).

AL Kanani (2001) mentioned four environmental circumstances blocking the creativity. These are:

1. The parents: The creative children might question the authority, rules and the adult's logic and interpretations and so, the behaviors of such children might be different. The parents might think that such behaviors could be bad and their reactions would be treating those children as abnormal children, naughty and not sensible. Those parents should know more about the nature of creativity by having special session discussing the creativity and sharing in the creativity process by themselves.

2. The school: The teacher might not understand or appreciate the creative child and then the child is demanded to be identical of others and to focus on academic sides in the lower basic stage, whereas a small amount of time is available for practicing the creative activities. The creative children might feel being oppressed to attend some uncreative classes and might reject to keep their creativity. The teacher should understand, appreciate and encourage the creativity of those children by supporting them by non- curricular activities which develop their creativity.

3. The role of both sexes: Such specific roles of boys and girls tie up those children to be unable of doing specific behaviors whenever discriminating between them according to their sex. This will take away the chance to grow up as normal individuals. Adults expect the males to be positive and independent, whereas the females are passive, dependent and very sensitive. According to such roles, those children lose their right 
in practicing quiet expressive activities and in particular the girls lose practicing strong activities.

4. The community, culture and traditions: It is distinguished concepts for each there are a specific collection of behaviors, values and attitudes which the children get at a very early age in a form of expectations. But the creative children have different and not familiar behaviors which cause them problems whenever the adults have all answers and expect those children to carry out special types of such behaviors. What suits some children do not suit others, but it is important to respect the effect of the expectations in relation with traditions and the individual's culture without sacrificing his/ her individuality.

Nowadays, we need learning and teaching strategies to support us by wide, variant and advanced educational horizons to help our students in developing their different mental skills and training them on creativity and producing new and different things. This demands the specialized teacher who gives the students a chance to contribute in putting the generalizations and experimenting it, in addition to providing them with the right resources and provoking and stimulating them for creative thinking and leading them to creative production. There should be alternative ways for problem solving (Egyptian community for curricula and instruction, 2000).

\section{Discussing the Findings of the Study}

\section{The results of the first question that implies "what is the role of the school in developing the children's creativity?".}

To answer this question, the researchers reviewed many studies that dealt with the role of the school in developing the students' creativity. The school could be the producing factor of creativity and creators and could also be the typical creative model for the creative community as a whole. The school should be a supportive creative tool which is represented in caring about and carrying out a number of suitable educational attitudes and activities that form the creative character, such as leaving feeding up learning which is the main enemy of creativity, in order to get a creative thinking or scientific mentality character (Abdel All, 2005). The responsibility of the school in preparing the creators is limited by the school roles in developing the creativity abilities for the students' such as developing the students creativity abilities and providing the facilities that show up such abilities. In addition, the teacher should help the student to perceive him/herself to feel his/her individuality clearly. Moreover, the school should give a chance for the student' to express his/her thoughts freely and realize the demanded creativity abilities of the student which is very crucial (Paul, 1969). The principal as the creative administrative leader in the school should be aware of the educational philosophies and the different teaching methods, in addition to the availability of the safe environment for the teacher and the student, as well. In addition, the principal should contribute in eliminating all things that make the students fear and worried inside the school. Moreover, s/he should care about the school maintenance to make it a clean and beautiful 
environment full of educational stimuli to be a motivated place for the creativity energy of the students (Abdel Majeed, 2005). Al Ma'itah(2007) and Abdel Majeed (2005) pointed out that the teacher has a basic important role in developing and caring about the creativity abilities of the students. In order to develop the creativity abilities of the students the school should stir up the students, feelings towards science and knowledge by planting academic and scientific attitudes inside them and offering brilliant models of struggle life stories of creative and successful scientists, artists and novelists. Having a scientific perception and scientific thinking ability is a real necessity in formulating the creative character (AL Kanani, 2011).According to what has been mentioned, the researchers came up with the following roles of the school in developing the students' creativity. These roles are as follows:

1. The education should develop the creativity abilities and direct each student according to his/her capability and concern, in addition to protecting each student's individuality and giving those students a chance to express themselves and showing up their abilities.

2. The teacher should plant the seeds of creativity in the students' minds and care about its growth. The teacher should use a new teaching strategy in pushing the students forward to challenge and accepting what is new and leaving out the traditional method of feeding up the knowledge to the students.

3. The classroom should be a stimulus environment for the new thoughts, activities and work including books, magazines, dictionaries, atlas, periodicals, movies, T.V, video, overhead projector and many other educational aids.

Many things, the teacher to prepare the creators and develop their abilities for example, developing their relations with other students, respecting each other, cooperating between them, preparing the classroom as an effective educational environment, flexibility in dealing with students, using effectively the motivational teaching strategies, helping the students to use what they have learned in facing their problems, using evaluative methods that explore the creative thinking expectation by stimulus questions and structural questions for collecting different thoughts (Ibrahim, 2001). The researchers stated that the teacher who develops the creativity is the one who establishes the solid ground of scientific thinking for the students. $\mathrm{S} /$ he encourages the students to state their problem and put forward questions to find out the right solutions. The students are trained by the teacher to have a judgment for any problem after real, deep, scientific thinking. The students also should be urged to question about anything to get the right conclusion or the kind of knowledge they are seeking for by knowing all reasons for any phenomenon. Having the word why, the students will understand and become more self-confident in dealing with any piece of information or any kind of knowledge. Teachers sometimes kill the distinguished abilities of creativity of the students because of blocking the different new thoughts and pushing the students to be fully obedient for the abstract and pervious known thoughts. As a result, the students lose their self-confidence and follow up the opinion of the group to keep their social relation and so they have a psychological struggle life of what is demanded from them and what new thoughts they have and most of them withdraw all what is related to creativity (Bakkar, 2005). 
The curriculum should gear the self-reading as a part of text book which enables the students to deal with different resources of cognition and gives a good part for practical areas (AL Zayed, 2008).

It is known that the curriculum neglects the full growth of the student and directs the caring for keeping the scientific material by heart in addition to the crowded curriculum of separated materials, for preparing the creative individual and developing the abilities of creativity by school, the previous method of teaching and the curriculum concept should be changed to push forward the creative students not backward (Abdel Majeed, 2005). It is crucial to consider the curriculum as a group of experiences prepared by the school to achieve a comprehensive growth for the students. Therefore, the concern will be with the student not with the material and the role of the teacher is not as connection between the textbook and the student's mind but as a guide and assistant for developing the students' abilities and launching their creative energy.

\subsection{The Curriculum in Our Schools is Still}

Suffering from the blocks that discriminate between the different branches of the specializations demands eliminating such blocks and having "the perfectness of the curriculum" by teaching the related materials together and presenting the curriculum topics as perfect units related to a specific lesson or social problems (Oweis, 2003). In order to develop the energy of creativity for the students, the researchers pointed out that the school curricula should get benefit from the huge progress of information technology in these days.

Nowadays with the marvelous developments in the world of information technology, it has become suitable for the school educational textbooks to deal with reality inside the school walls by the availability of multi direct communications for the students with sources of cognition outside school. There are some ways should be followed for developing the creativity spirit for our students, such as preparing the suitable school environment for practicing the thinking skills as library and laboratories, school curricula planning for developing the creative thinking, assigning a part of the curriculum for creative thinking, focusing on problem solving by using scientific thinking steps, developing the students' abilities of creative, structural thinking and self- criticism, organizing contests and scientific debates for talented and creative individuals and providing different domain of school activities to feed the tendencies of the excellent students in writing, public speaking poetry and painting ( Abdel Majeed, 2005).

\section{Discussion of the findings of the second question that implies "What is the role of the family in developing the children's' creativity?"}

To answer this question, the researchers got through the role of the family in developing creativity by consulting many studies that showed the importance of the family's role in developing creativity. The parents always have real documented history of the child's character, abilities and needs. This parental vision could be an important source for teachers to understand the child and then raise him/her creativity (Robin, 1993). In fact, the grown up creative child is definitely the one who was raised in a special way in his/her childhood 
because the child's early years are the internal motivational factors of success or failure for the his/her future life. The creative adult had the warmth of family and good appreciation, and enjoyed an amount of initiation and independency in their first life years. This encouraged them to search and explore, in addition to having the encouragement in confronting the problems and trying to solve it while looking for new experiences (Oweis, 2003). The researchers stated that fear and pressing inside the expression of thoughts are resulted from the strict discipline the family practiced on their children which made the child in-confident of his words and actions, as well. Therefore, educating the family of their important role in encouraging the initiation, independency and getting what's new are considered basic demands for developing children's' creativity. The family could help teacher to know about their children's tendencies and abilities and also the family could care about those abilities and develop it. For doing that, the family should provide love, caring and warmth of the family to their children and set a good example for them. In addition, the non-curriculum books, such as dictionaries, periodicals, magazines and children's books should be available in the house (Abdel Majeed, 2005).Children who used to be controlled and strictly disciplined would accept to be oppressed in their thinking as they grow up unlike the independent ones. The researchers pointed out that the family is the basic school and the first step in the encouragement and reinforcement which affects the child's behaviors, manners, morals and language(Oweis.2003).The family is a very sensitive and dangerous lab for the children, it could be a factory of bravery, scientists and good mannered persons or a factory for careless, criminals or troublesome persons (AL Naser, 2001).

Religious raising up and the encouragement for reading Holy Quran (the Heaven book) and keeping it by heart would refine the children's' characters and comfort their souls and as a result would be calm and creative, as well (Abdel Mu'ti, 2006).

Farshoukh (1992) stated that Ibn Seena was able to recite Holy Quran when he was below ten years. Akawi(1993)also pointed out that Imam Shafi'i learned Holy Quran when he was seven and also kept it by heart all Prophet Mohamad's (PUH) sayings (HadeethShareef).The researchers concluded from what has been mentioned that the family could contribute psychologically for developing the children's' creativity spirit by supporting them with love and passion which has a great influence on the children's' progress and creativity. By encouragement and reinforcement, the child will be nourished and grown healthy, whereas this child's abilities and creativity would be killed by blaming, neglecting and with less caring and love. The family could plant the love for reading in the children as being the main mean of knowledge and the most effective in developing the ability of thinking (Adas, 2005). The researchers stated that reading is a vital necessity for life as being the basic element in the process of raising children. SayedQutub (1982) stated that "This Islamic nation needs creativity for building up life on earth. Prophet Mohamad (PUH) chose leaders who had the quality of creativity, such as khaled bin al Waleed who was assigned a leader for a big army troop whenever opening Mecca and freeing it from the disbelievers, in addition to his leadership in mu'tah battle and other it brave situations(Sweden, 2004).The researchers point out that creativity is a mean of education in Islamic method which has special effect on one's thought and psychology, as well. Therefore, creativity in the Islamic vision has a purpose in 
urging the Muslim to achieve his/her role in this life perfectly.

\subsection{Discussion of the Findings of the Third Question}

It implies "What are the proposed activities of the school and the family to develop the children's' literary creativity abilities? To answer this question, the researchers got through many studies that dealt with children's' literary creativity, in particular, in story writing, in addition to some proposed activities for developing the children's story writing creativity in the family and in school, as well. The story is an effective means in the modern education which enables the students a chance for understanding and in showing up their talents and skills. In addition, the story grows up their right thinking and encourages them to express themselves orally correctly by getting used to reciting, summarizing and acting (AL Hashmi, 2009). The story also is a means in developing the individual's creativity and imagination because it includes different events and situations urging one's mind to form relations and connections between the different components and events of the story. It is a tool moving man's emotions, imagination and thinking (Abdel mu'ti, 2006).

The researchers stated that the Islamic method considered the importance of the story as many stories mentioned in Holy Quran. Some studies focused on developing basic stage students' creativity such as AL Nakhali's(2004), AL Ghamidi's (2001) and Mosa's (2002). The researchers also suggested a number of activities and steps to be followed by the family to train their children on writing stories. For examples, the family recites a story from Holy Quran as the story of Prophet Moses (PUH) and Bani Israel, Holy land, Dual Qarnain, Prophet Joseph's story and Prophet Jaccob's story, Peace Upon Them. The family also could narrate the following stories for their children:

- $\quad$ Prophets 'stories that were told by Prophet Mohamad's(PUH) to his followers, such as Ibrahim's and Ismail's and his mother's story. The bald's blind's story, AL Ukhdud boy's story, the three persons in the café story, and others.

- $\quad$ The popular stories that are in harmony with the characteristics and stages of their children's growth.

- $\quad$ The translated stories, the past stories and the autobiography stories.

- $\quad$ The stories of great persons, perils and wars.

- $\quad$ The stories that encourage the creativity as the creative scientists' stories who offered good contributions for the world and for Islamic nation. The children tend to imitate the roles of such people by offering similar contributions and achievements.

- $\quad$ The family could help their children to discriminate between the parts of the story to be much more aware during reading and also to simplify them the way to write their own stories.

- $\quad$ The family could prepare a story to be read for the children each week and those children will be asked to identify the story components.

The researchers identified the following activities and steps to be followed by the school in 
teaching the story to the children. These are:

- $\quad$ Story orientation by showing the pictures of the story characters, imitating the animals voices, raising some questions related to the events of the story, reading it and discussing it, in addition to story acting.

The teacher should consider the following:

1. Distributing the roles in a suitable way for the children.

2. Preparing suitable conditions close to the setting of the story.

3. Preparing the suitable tools and costumes which add reality for the story.

The teacher should follow up the children's' roles in the story by acting it properly, pronouncing correctly and keeping all those roles by heart.

\section{Recommendations}

- $\quad$ Parents should care about their children's' creativity to succeed in building up a good generation for the coming years by following up everything new in the libraries about creativity and training programs.

- A necessity for cooperation between the school and the family to make creativity.

- Provoking the students to practice creative thinking skills by activating creative thinking in teaching methods and combining the creative thinking in all school programs.

- $\quad$ Creating an environment that encourages creative thinking, giving time for discussion and preparing the students to be able of creative thinking.

\section{References}

Abdel Al Hasan, Ibrahim. (2005). Creativity Education (Presence Necessity). Amman: Dar al Fikr.

Abdel Jaleel, Ali. (2005). Writing Story Art. Amman: Dar Osama for publication.

Abdel Majeed , Jamil. (2005). Children's Activities of Creativity. Amman: Dar safa'.

Abdel Mu'ti \& Abdullah Mohamad. (2006). How to Make a Child. Cairo: Dar alEslamiyah for publication.

Abdullah, Sa'dal Dean. (2001). Creativity in peace and War. Cairo: Vocational Administration Experience Center.

Abu al Nasir, Med hat. (2003). Caring the special ability persons. Cairo: Arab Nile Group.

Abu Jadu, Saleh. (2004). Practical Applications in Creative Thinking. Amman: Dar al 
Shuruq.

Abu Rizq, Ibtihal Mahmud. (2002). The Effect ofa Proposed Program on Developing Composition in Arabic language for the Basic Tenth Class in Jordan. UnpublishedM.A. Thesis. University of Jordan. Amman: Jordan.

Adas, Mohamad. (2005). The Role of self- reading in developing thinking. Amman: Dar al Fikr al Arabi.

Akawi, Rehab khader. (1993). Periodical of Muslim Enginius in Syntax, Language and Story. Beirut: Dar al Fikr al Arabi.

AL ALbani, Mohamad. (1986). Saheeh al Jami, al Sagheer and its additions (AL Fateh al kabeer) v (2). Beirut: Dar al Kutub al Eslami.

Al Ashmawi, Huda. (2009). Developing the creative Thinking as a possible Mission. Magalat al Ma'rifah n.(157): Saudi Arabia.

Al Assaf, Saleh. (2000). An Introduction to Research in Behavioral sciences. V(2). Riyadh: AL Ebekan library.

Al Ezzah, Sa'eed. (2001). Educating Tanleted and Distinguished. Amman: Dar al Thaqafa.

Al Ghamedi, Saleh. (2001). Creative Thinking for the Middle Stage Students in Jazan Area: A Comparative Study. Unpublished M.A. Thesis: Um al Qurauniversity.

Al Hadeedi, Ali. (1996). Children's literature.v (7). Cairo: Egyptian Anglo library.

Al Haj Ali Beck, Muhanad. (2009). Wa Almnahuswhu. Damascus: Dar AL Fikr.The Egyptian Committee for Curriculum and Instruction (2000). Studies of the $13^{\text {th }}$ scientific Conference about Educational Curricula and Developing Thinking.25-26.Ein Shams University.

Al Hashmi, Abdel Rahman \& et al. (2009). Children's literature and Philosophy, Types and its Teaching. Amman: Dar Zahran.

Al Huwaidi, Zaid. (2004). Creativity. Al Ein Dar al kitab al Jami 'I.

Al Kanani, Mamdouh. (2011). Readings in Child's Creativity, V(1). Amman: Dar al Maseerah.

Al Khalailah, Abdel Kareem AL Lababedi, Afaf. (1997). Methods of Teaching Children Thinking. Amman: DAR al Fikr.

Al Khaleeli, Amal ABDEL Salam. (2005). Developing children's creativity Abilities. Amman: Dar al Safa'.

Al Khateeb, Khaleel. (2000). Arts of literary Writing for the International Secondary Students. Amman: Dar al Shuruq.

Al Ma'itah, khalil. (2007). Talent and Distinguishing, v(3). Amman: Dar Fikr. 
Al Nakhali's, Ahmad. (2004). Developing Creative Abilities for a Sample ofElementary Stage Students in AL Ta'if Governorate. Unpublished M.A. Thesis:Um al Qura University.

Al Naser, Mohamad Hamid, Darweesh \& Khawla Abdel Qader. (2001). Educating children in Islam at home and kindersgarten, Vol(4). Jeddah: AL Sawari library.

Al Sairafi, Mohamad. (2006). Thought Administration. Al Eskandarya: International Horus Institution.

Al Shanqiti, Mohamad. (2005). A Proposed Vision for Developing the Creative Thinking for the Secondary Stage Students from Islamic Education Perception. Unpublished M.A. Thesis: um al Qura university.

Al Sweidan, Tariq Mohamad, Ba Sharhabeel \& Faisal Omar. (2004). Making leaders. Riyadh: Jareer library.

Al Teti, Mohamad. (2001). Developing Creative Thinking Abilities. Riyadh: Daral Maseerah.

Al Zahrani, Misfer Sa'eed. (2003). Strategies for showing up the Talented and creative and caring them. Mecca: Dar Teba AL Khadra'.

Al Zayed, Tayseer. (2008). For a Better Future (Encouraging children for creativity). Magalaat AL Mughtama.

Bakkar, Abdel Kareem. (2001). An Introduction to Perfect Development. Dmascus: DaralQalam.

Cormack, Rumiana. (2004). Creative Drama in Writing Process.The Impact on Elementary Students' Short Story.[M .Ed. dissertation]. Canada: university of northern British Columbia.

Fareed, Amad. (2008). Education According to the Method of Ahl al Sunna and al Jama'ah. Riyadh: Dar Teba.

Farshukh, Mohamad Ameen. (1992). Periodical of Muslin Enginius. Beirut: Amman: Dar al Fikr al Arabi.

Habash, Zeinab. (2002). Educational Horizons in Creative Teaching and Learning. Ramallah: AL Anqa' Institution for Renewing and creativity.

Hijazi, Sana Ahmad. (2006). Psychology of Creativity. Cairo: Dar al Fikr al Arabi.

Hussein, Tha'er. (2007). Comprehensive Thinking Skill.v/.(1). Amman: Debono center for publication.

IbnManzour, Jamalal. (1997). Lisan al Arab.v(6). Beirut: Dar Sader.

Ibrahim, Abdel Sattar. (2001). New Horizons in Studing Creativity. Kuwait: Publication Agency.

Jarwan, Fathi Abdel Rahman. (1999). Creativity. Amman: Dar al Fikr. 
Krobli, Arther J. (2006). Creativity in Learning and Teaching. Translation of Abdel Hakeem al khuzami. Cairo: Dar al fajer.

Mohamad, Huda Mustafa \& Abdel Majeed\&Osama Mohamad. (2005). A Proposed Program for Developing Creative Writing by Using Brain Storming for the Linguistic Talented Students and its Effect on Reading Comprehension. Einshams university: faculty of education. The Egyptian committee for reading and knowledge, 125(50)-137.

Mousa, Mostafa Ismail. (2002). The Effect of a Proposed Program in Developing someSkills in Creative Writing: Story Domain and the Story Writing a Wareness for the Fifth Elementary Students- Dirasat in Curricula and Teaching Methods. Ein shams university, 214(77)-259.

Najem, Mohamad Yusuf. (1995). Art of Story Writing ed.(7). Beirut: Dar al Thaqafa.

Obeid, Majeda al Sayed. (2000).Educating the Talented and Distinguished. Amman: Dar al safa'.

Obeidat, Duqan \& et al. (2001). Scientific Research its Concept, Tools and Methods. Amman: Dar al Fikr.

Oweis, Afaf Ahmad. (2003). Children's Creativity Psychology ed.(1). Amman: Dar al Fikr.

Paul E. Torance. (1969). Gidding Creativity Talent. (prentice Hall of India Private Limit: new Delhi, p.7.

Qatami, Naifa. (2005). Educating Creativity to Children. Amman: Dar al Fikr.

Robin, Higgins. (1993). Creativity and Under Functioning: Some Consequences forSociety.In vedverma.(ed). How and why children Fail Jessica kingsley publishers: London and Philadelphia.p.1

Sayed Qutub. (1982). In the Shadow of Holy Quran. ed.(10). Beirut: Dar al Shuruq.

\section{Copyright Disclaimer}

Copyright reserved by the author(s).

This article is an open-access article distributed under the terms and conditions of the CreativeCommons Attribution license (http://creativecommons.org/licenses/by/3.0/). 